Supplement of Biogeosciences, 16, 3725-3746, 2019

https://doi.org/10.5194/bg-16-3725-2019-supplement

(C) Author(s) 2019. This work is distributed under

the Creative Commons Attribution 4.0 License.

(c) (1)

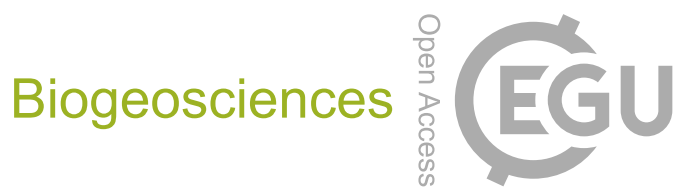

Supplement of

\title{
Effects of eutrophication on sedimentary organic carbon cycling in five temperate lakes
}

Annika Fiskal et al.

Correspondence to: Annika Fiskal (annika.fiskal@usys.ethz.ch) and Mark A. Lever (mark.lever@usys.ethz.ch)

The copyright of individual parts of the supplement might differ from the CC BY 4.0 License. 


\section{S1 Supple mentary Text: Lake Site description (extended)}

\section{Lake Greifen}

5 By 1900 the anthropogenic activity acting on Lake Greifen had increased strongly (higher population, more infrastructure and traffic) and already between 1918 to 1932, 7 mass deaths of fish were reported. Since 1930 severe eutrophication started in Lake Greifen. Between 1965 and 1977 water treatment plants were build, developed and later on (1981 to 1986) equipped with phosphorus (P) precipitation systems. Still around 1970 the highest $\mathrm{P}$ concentrations were measured and in 1987 high water column chlorophyll $a$ concentrations were recorded (Liechti, 1994; Känel, 2012). In 1999 an anoxic event lead to a massive

10 fish die-off. In 2009 an artificial ventilation system with air was introduced to improve lake water conditions. Thereby air is pumped down into the lake water column and released with distributors creating fine bubbles, which enrich the water with oxygen and support mixing. Nevertheless, in 2010 high $\mathrm{P}$ concentration were measured due to multiple winters with weak circulation. Today the tributaries of the lake remain highly contaminated with nutrients and pollutants from sewage and agriculture. The thermal stratification lasts approximately from May to December. During summer stratification (June to

15 December) the hypolimnion becomes anoxic below $10 \mathrm{~m}$ water depth (Kümmerlin and Matzinger, 2008; Känel, 2012).

\section{Lake Baldegg}

Clear signs of eutrophication have been evident in Lake Baldegg since the late $19^{\text {th }}$ century, with the first cyanobacterial blooms (Oscillatoria rubescens) reported in the 1870s, and bottom water anoxia documented below 60m water depth around 1885

20 (Lotter, 1998; Teranes et al., 1999; Lotter, 2001). As anthropogenic activity increased further in the early $20^{\text {th }}$ century due to industrialization and increased human settlement, an increasing volume of water was diverted into the lake from industry and villages. This lead to seasonal anoxia below $40 \mathrm{~m}$ water depth by 1940 (Liechti, 1994). From 1965 onward, agricultural use of the lake drainage area intensified (e.g. stock of swine), which lead to over-fertilization and an increase of nutrients in the lake. In 1967 the water treatment started. In 1970 anoxia was found to occur below $10 \mathrm{~m}$ water depth and in 1974 the highest P concentrations were measured (Buergi and Stadelmann, 2000). In 1980 additonal water treatment plants were added and equipped with $\mathrm{P}$ precipitation systems. Thereby $\mathrm{P}$ is co-precipitated with coagulants, usually metals like $\mathrm{Fe}$ and or $\mathrm{Al}$ and removed afterwards. Since 1982/3 the net circulation of the lake is enhanced using pressured air in winter to mix the lake completely, in summer fine bubbles of $\mathrm{O}_{2}$ are introduced (Stadelmann and Escher, 2002). Since $\mathrm{O}_{2}$ levels increased, macrofauna can be found again in the lake sediments. 


\section{Lake Zug}

Lake Zug was influenced by anthropogenic activities already between 1830 and 1860 by construction of the first factories followed by strong increase in population from 1850 onwards. First sights of eutrophication in 1898 by the occurrence of algae blooms occurred. Agriculture activities increased from 1940 onwards and population increasing strongly as well as animal

5 stock. Since 1940/50: low $\mathrm{O}_{2}$ or even anoxic conditions occur at greater depths. In 1953 water treatment plants are build and extended in 1968, between 1973 to 1977 more water treatment plants are added (Liechti, 1994). From 1980 onwards animals stock is decreasing again as well as usage of fertilizers. Between 1993 and 1999 agriculture techniques develop towards higher ecological responsibility. Since 1994 eutrophication decreased slightly (Maerki et al., 2009). Nowadays, Lake Zug has an annually mixed water column to a depth of 50-80 m (rarely exceeding $100 \mathrm{~m}$ ). At the sediment water interface $\mathrm{O}_{2}$ decreases 10 sharply.

\section{Lake Zürich}

Lake Zürich sedimentary records reveal massive blooms of algae because of eutrophication already in 1896 and 1898 (Livingstone, 2003; Jankowski and Weyhenmeyer, 2006). Before 1955 low bottom water (BW) $\mathrm{O}_{2}$ due to eutrophication was

15 recorded. Also in 1955 water treatment plans were introduced. Better conditions established from 1970 onwards, less P input and higher $\mathrm{O}_{2}$ in BW due to better-implemented P removal (AWEL 2014) was achived. Between 1967 and 1970, the water treatment plants were equipped with P precipitation systems and from 1994 onwards they were extended with special flocculation/coagulation filtration ((Liechti, 1994), AWEL 2014). Due to the water treatment actions, the lake changes from a eutrophic to mesotrophic state. Since $2000 \mathrm{O}_{2}$ declined again, probably related to climate change and the increasing temperature related to it (Cole et al., 2007). Thus, mixing intensities are reduced because of stratification, which reduced BW $\mathrm{O}_{2}$ renewal. Today the "Untersee" of lake Zürich is mixed regularly until $80 \mathrm{~m}$ water depth but only every few years to the ground (Känel, 2012). During summer high thermal stratification occurs, with a thermocline between 7.5 and $12.5 \mathrm{~m}$ (Gammeter et al., 1997; Gammeter et al., 2002).

\section{Lake Lucerne}

Since 1860 the catchment area of Lake Lucerne was influenced by higher population densities, which influenced water quality. At the end of the $19^{\text {th }}$ century the city of Luzerne develop towards an international tourismus metropole which lead to the extension of the canalization system and the discharge of sewage water into the lake (BAFU, 2013). In 1931 the first water treatment plant was build. Since 1966 the lake water nutrients increased significantly (Staub et al., 1981). More protection of

30 the lake was introduced since 1971-1999 to reduce nutrients loadings by building and extending water treatment plants (Liechti, 1994). Nowadays a complete overturn occurs every 6 years (BFS 2010 and BAFU, 2013). The water column is naturally oxygenated and in general Lake Lucerne has low nutrient concentrations but relatively high Nitrate concentrations can be found $(63 \mu \mathrm{M})$ in the water column (Vissers et al., 2013). 


\section{S2 Supplementary Text: Detailed description of redox state analysis of the sediment}

Mediated electrochemical reduction (MER) and oxidation (MEO) was performed in electroche mical cells (Glassy carbon crucibles (GAZ1; Sigradur G, HTW, Germany), that also served as the working electrodes, and were filled with $6 \mathrm{ml}$ of anoxic buffer ( $\mathrm{pH}$ 5, $0.01 \mathrm{M}$ acetate, $0.1 \mathrm{M} \mathrm{KCl}$ ). A Pt wire served as counter electrode and was placed in a compartment separated

5 from the working electrode by a porous glass frit. Potentials applied to the working electrodes were measured against $\mathrm{Ag} / \mathrm{AgCl}$ reference electrodes (Bioanalytical Systems Inc., USA) but are reported herein versus standard hydrogen electrode $\left(\mathrm{E}_{\mathrm{h}}=-\right.$ $0.65 \mathrm{~V}$ and $+0.58 \mathrm{~V}$ for MER and MEO, respectively). The MER and MEO cells contain the dissolved electron transfer mediators 1,1'-Ethylene-2,2'-bipyridinium dibromide (diquat) and 2,2'-Azino-bis(3-ethylbenzothiazoline-6-sulfonic acid) diammonium salt, respectively, to facilitate electron transfer between the working electrode of the electrochemical cells and

10 the redox-active constituents in the sediment. Addition of $50 \mu \mathrm{l}$ of sample slurries to the MER and MEO cells resulted in reductive and oxidative current responses that were integrated (software ORIGIN 9.1) to yield the number of electrons transferred to and from the sediment samples, as detailed before (Kluepfel et al., 2014; Klupfel et al., 2014; Sander et al., 2015).

\section{S3 Supple mentary Text: Focusing Factor calculation}

15 However focusing factors (FF) were calculated for comparison using the ratio of the measured inventory of ${ }^{210} \mathrm{~Pb}\left(I_{m}\right)$ in Bq/cm and the expected inventory of ${ }^{210} \mathrm{~Pb}\left(I_{e}\right)$ in $\mathrm{Bq} / \mathrm{cm}^{2}$ after the following formula (Hermanson and Christensen, 1991):

$$
\begin{gathered}
I_{m}=\sum_{i}^{N} p_{i} s_{i} \Delta z_{i} \\
I_{a}=\sum_{i}^{N} F_{i} e^{-\lambda t}
\end{gathered}
$$

Where $i$ is the core layer, $N$ is the deepest layer where the ${ }^{210} \mathrm{~Pb}$ was found, $p i$ is dry bulk density $\left(\mathrm{g} / \mathrm{cm}^{3}\right)$, si is activity $(\mathrm{Bq} / \mathrm{g})$ and $\Delta z i$ is layer height $(\mathrm{cm})$ of the $\mathrm{i}^{\text {th }}$ layer. $F i$ is atmospheric input of ${ }^{210} \mathrm{~Pb}$ and was estimated from precipitation (average local weather stations, 1961-2010). $\lambda$ is the decay constant for the nuclide and $t$ is the number of years the nuclide was in the sediment (Hermanson and Christensen, 1991). The FF is then calculated as $\mathrm{FF}=I_{m} / I_{a}$. 


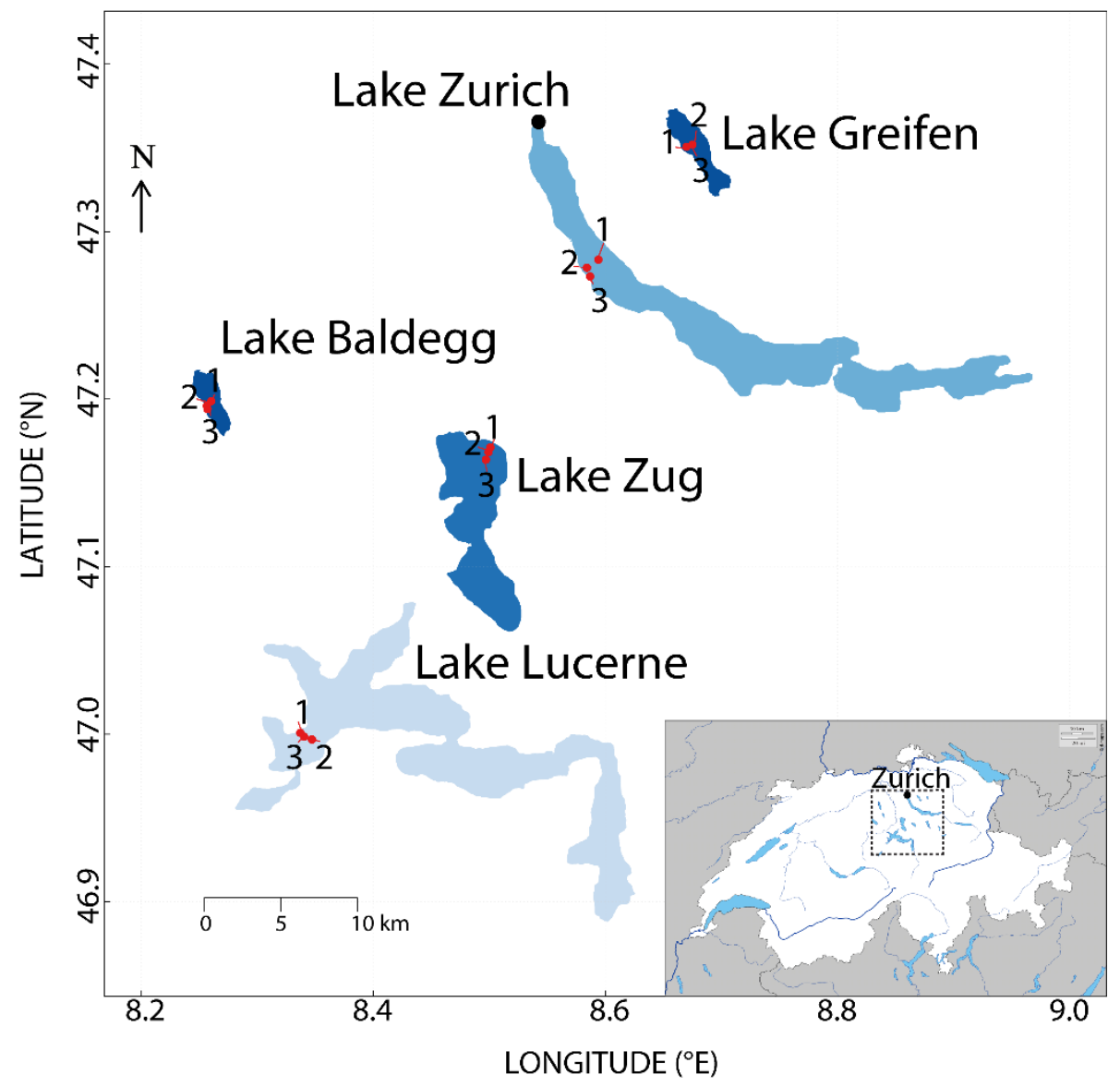

Figure S1: Map of the study area. The sampling stations within each of the five lakes are indicated by red dots and numbered 1 to 3. Color indicates trophic state from light blue (oligotrophic) to dark blue (eutrophic). This map contains data based on aerial images from DigitalGlobe (CO) and CNES/Airbus (France) as provided by Google (CA) and was created with the software R (South, 2011). 5 Small insert map from d-maps (https://www.d-maps.com/carte.php?num_car=2648\&lang=en). 


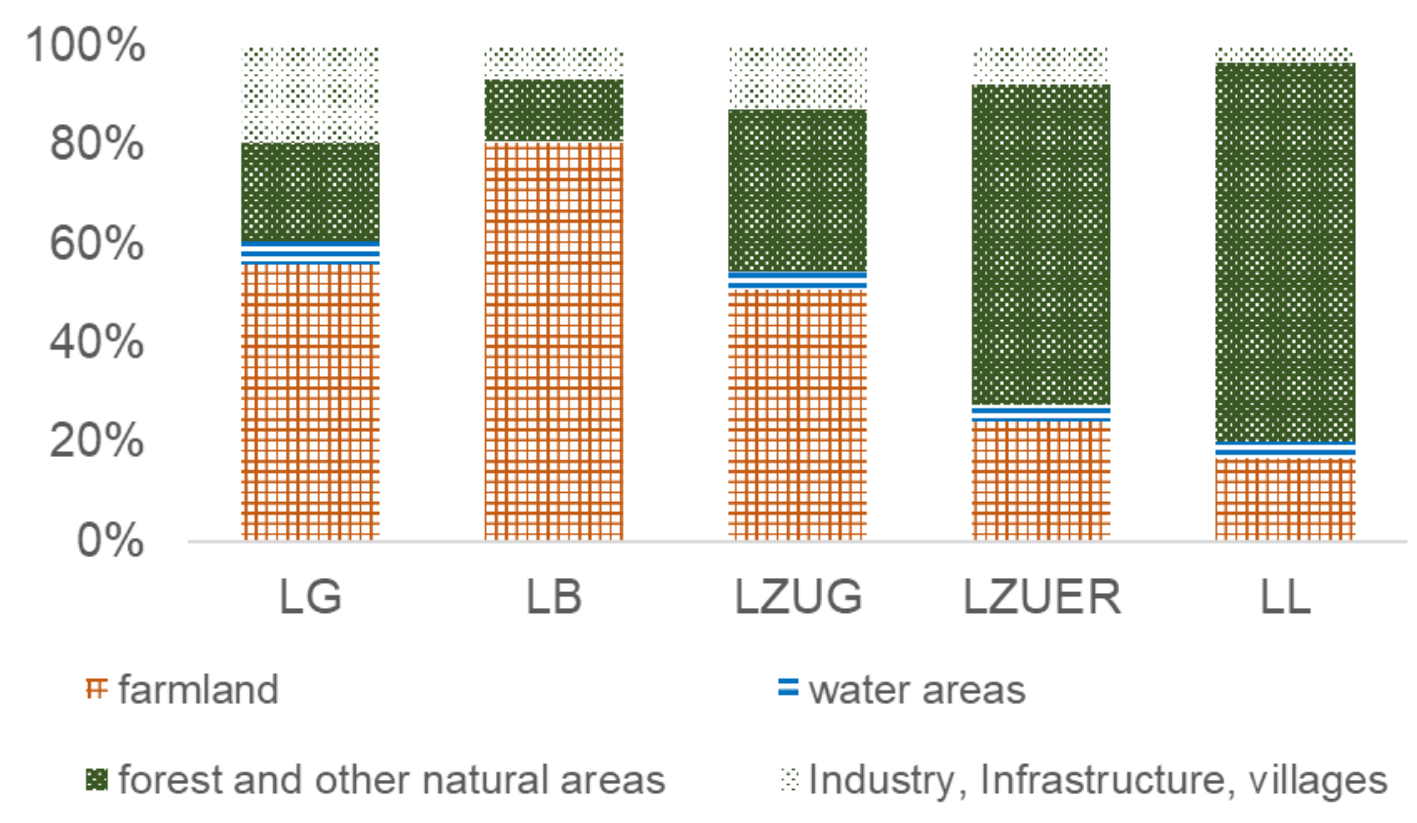

Figure S2: Present-day land use of lake drainage area in \%, LG (Lake Greifen), LB (Lake Baldegg), LZUG (Lake Zug), LZUER (Lake Zurich), LL (Lake Lucerne). Data were provide by the EEA (2010), Swiss Federal Office of the Environment (BAFU (2013)). https://www.bafu.admin.ch/bafu/en/home/topics/water/info-specialists/state-of-waterbodies/state-of-lakes/water-quality-in5 lakes.html

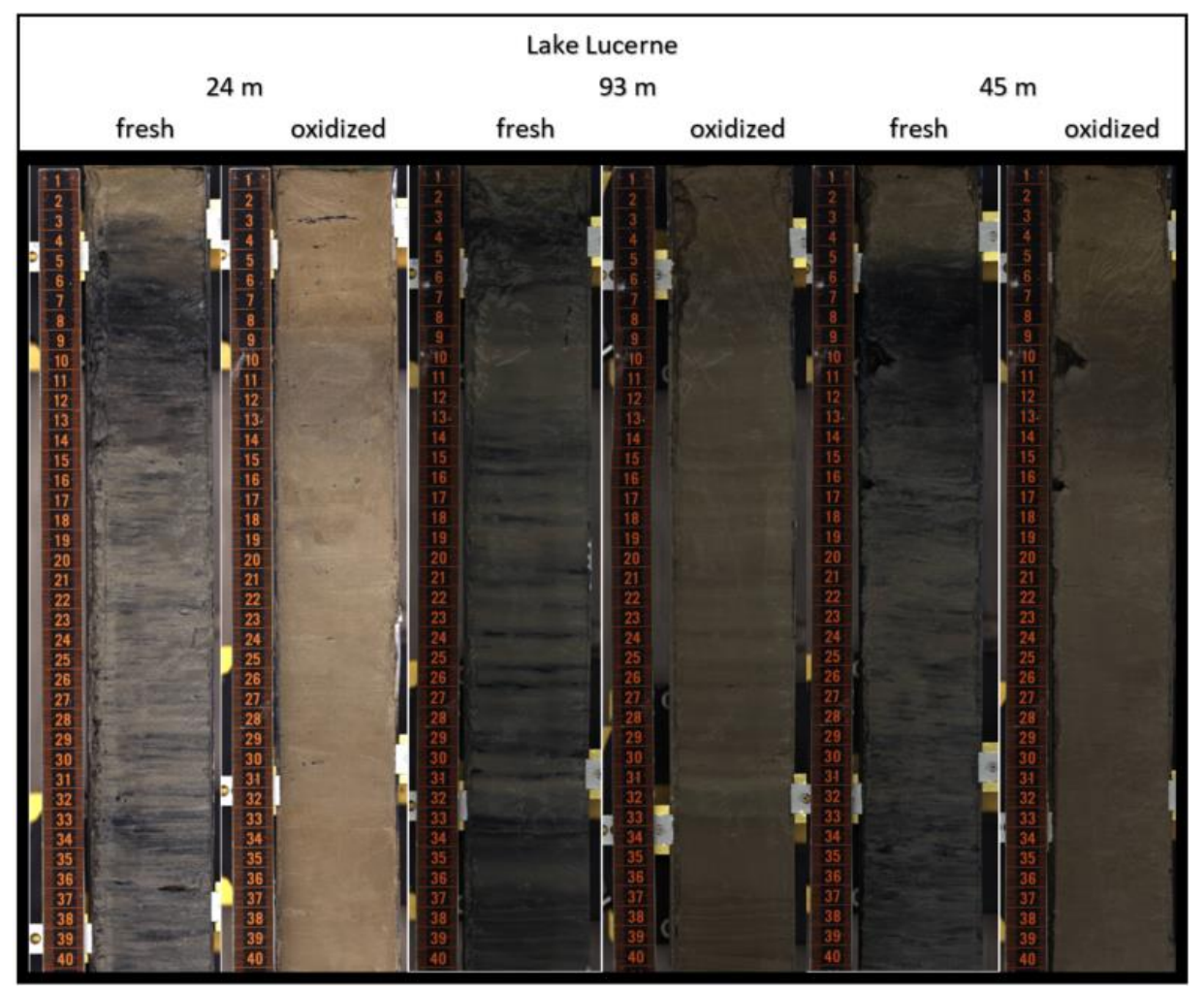



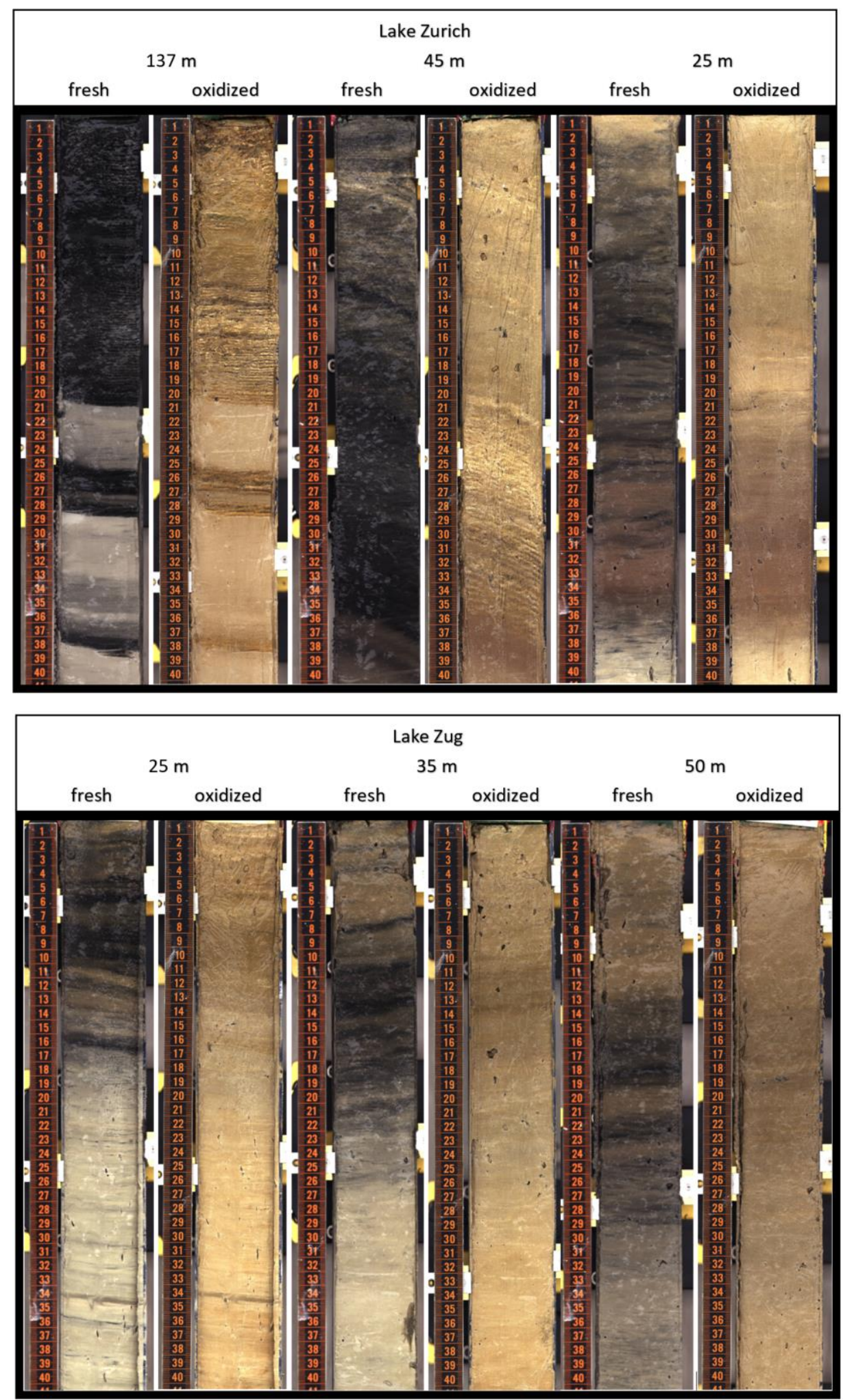

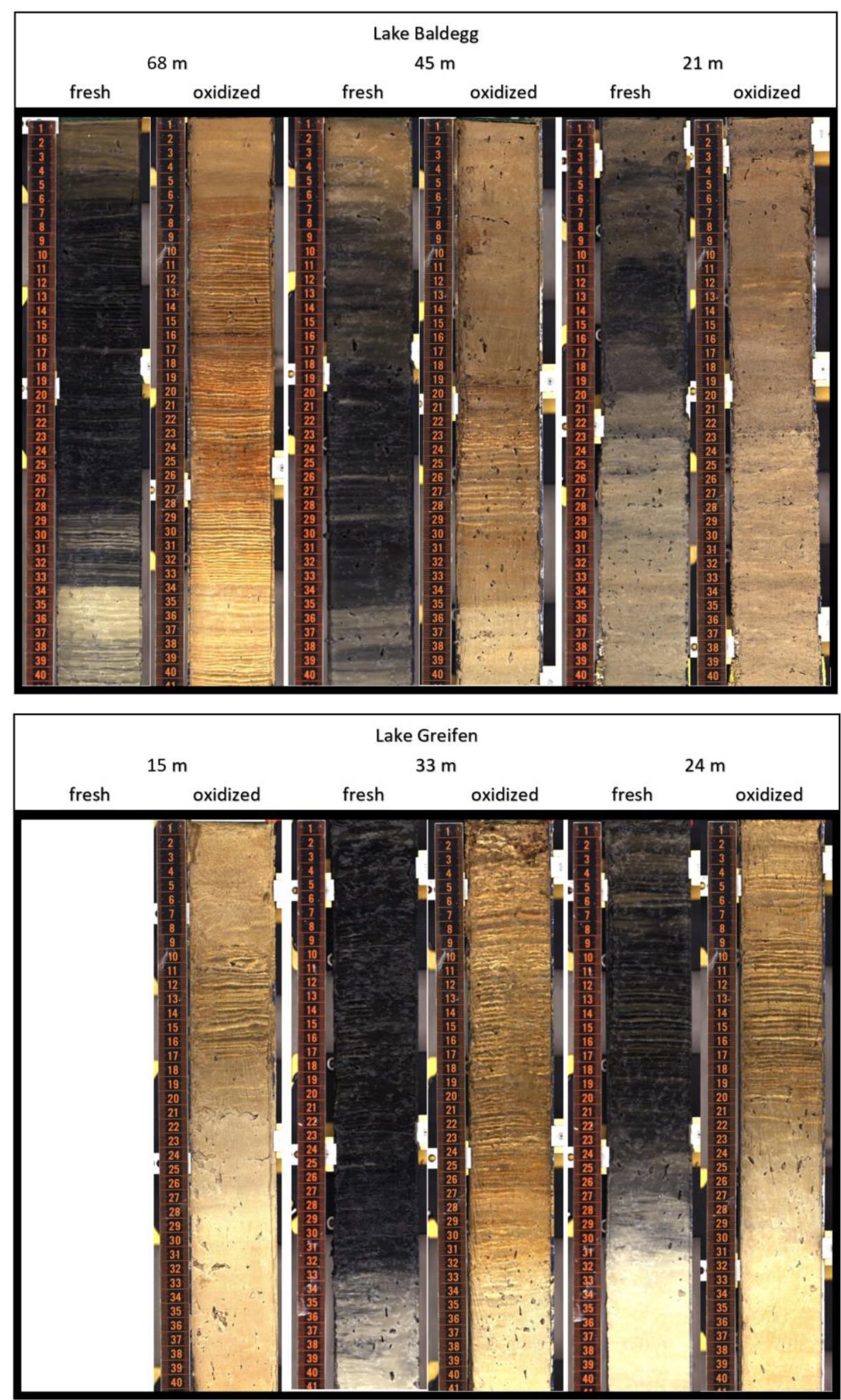

Figure S3: Core pictures for each station, directly after opening (fresh) and after stored opened in air (oxidized). Lake Name and water depth are indicated for each lake (Lake Lucerne, Lake Zurich, Lake Zug, Lake Baldegg, Lake Greifen). 

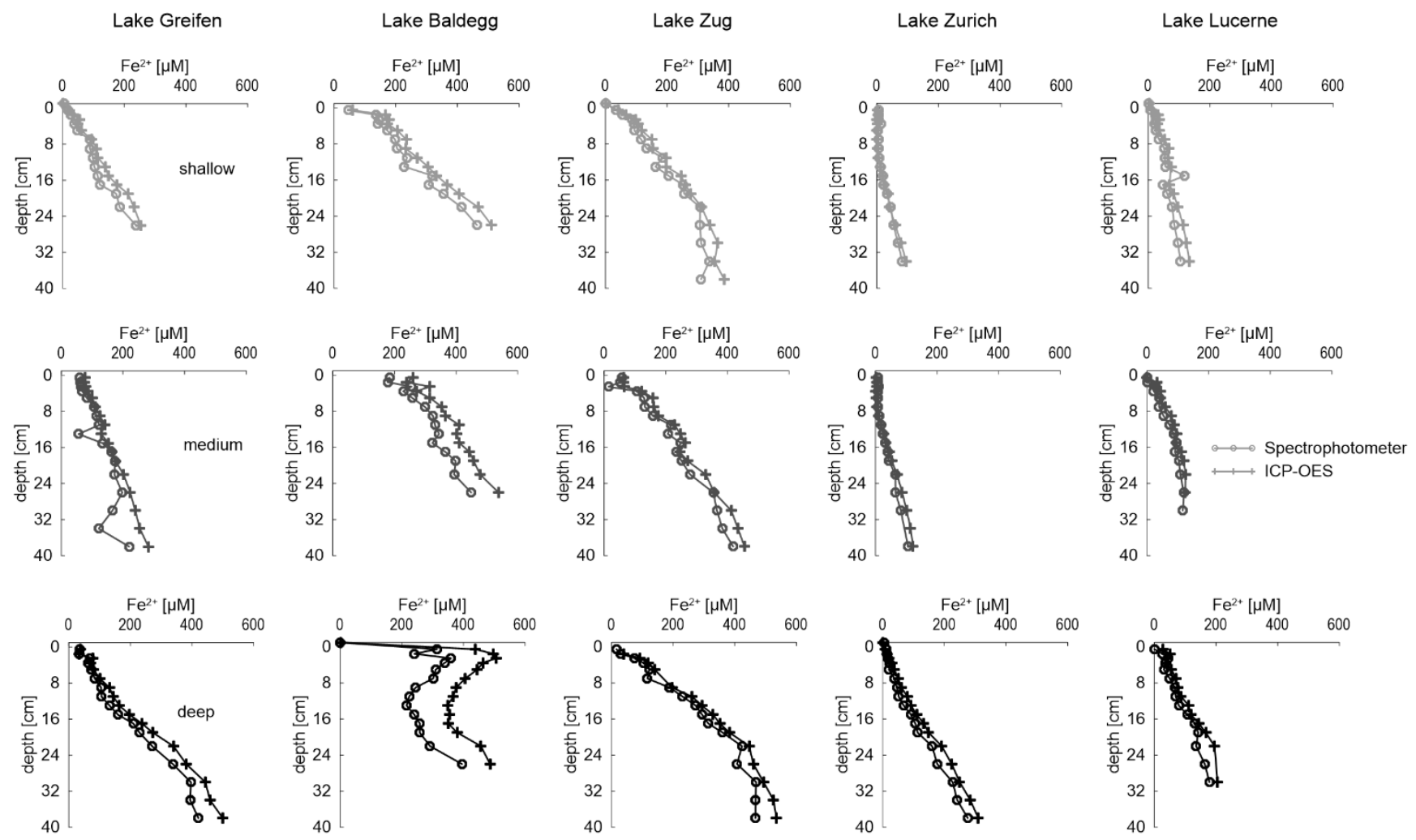

Figure S4: Porewater concentrations of $\mathrm{Fe}^{2+}(\mu \mathrm{M})$ determined photometrically (circles) and by ICP-OES (plus signs) for each station. Stations are ordered according to water depth from shallow to deep and by eutrophication from highly eutrophic Lake Greifen to Lake Lucerne.
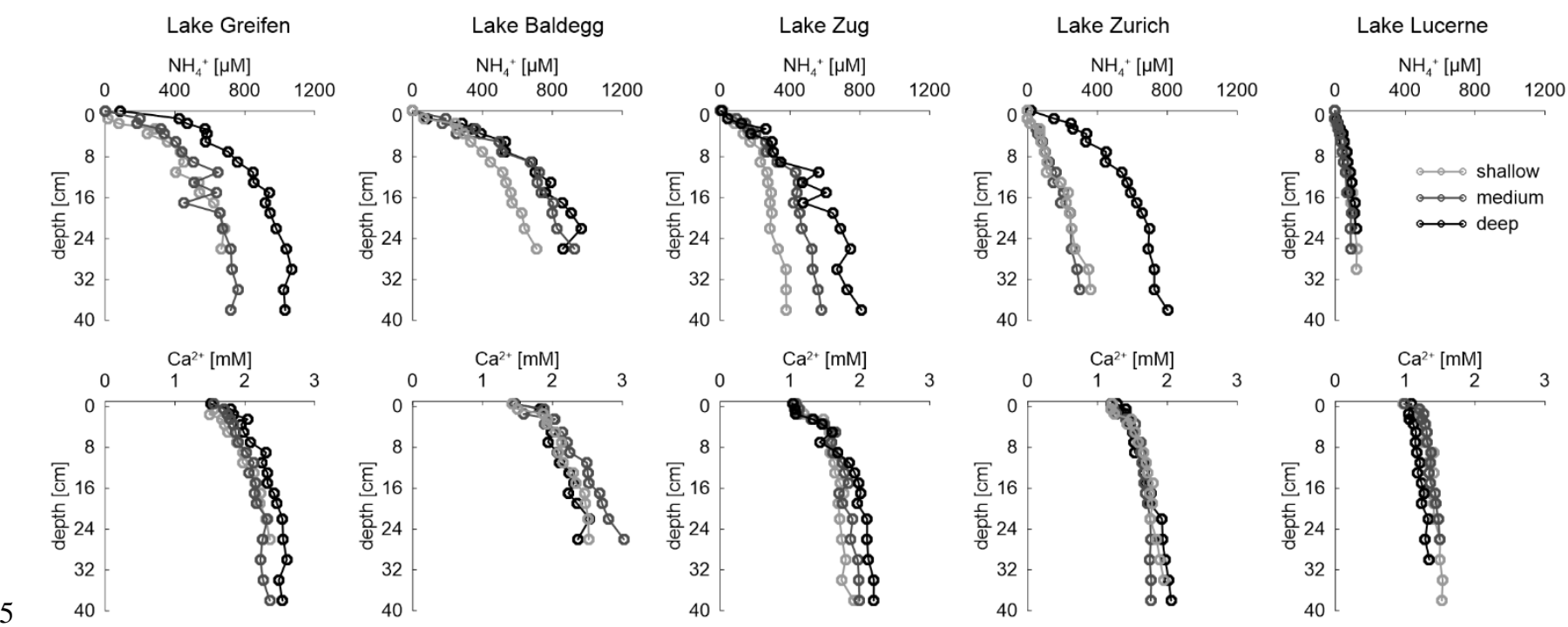

Figu re S5: Porewater concentrations of $\mathrm{NH}_{4}^{+}(\mu \mathrm{M})$ and $\mathrm{Ca}^{2+}(\mathrm{mM})$ vs. sediment depth $(\mathrm{cm})$. All three stations per lake are shown in each subplot. 

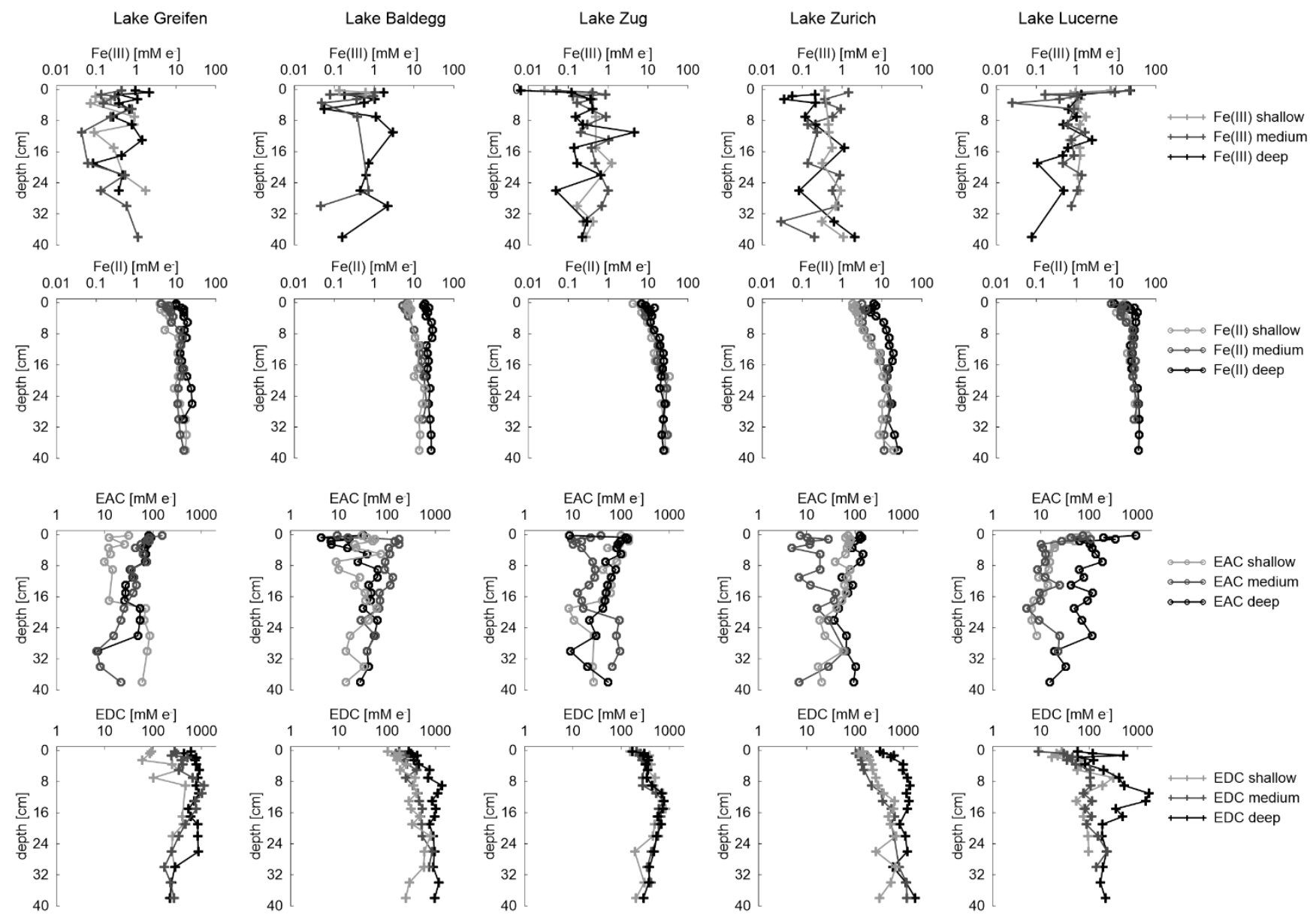

Figure S6: Bioavailable solid phase Fe(II) and Fe(III) as well as EDC and EAC for each lake. Each subplot shows 3 stations per lake. Note concentrations are per liter of wet sediment. 


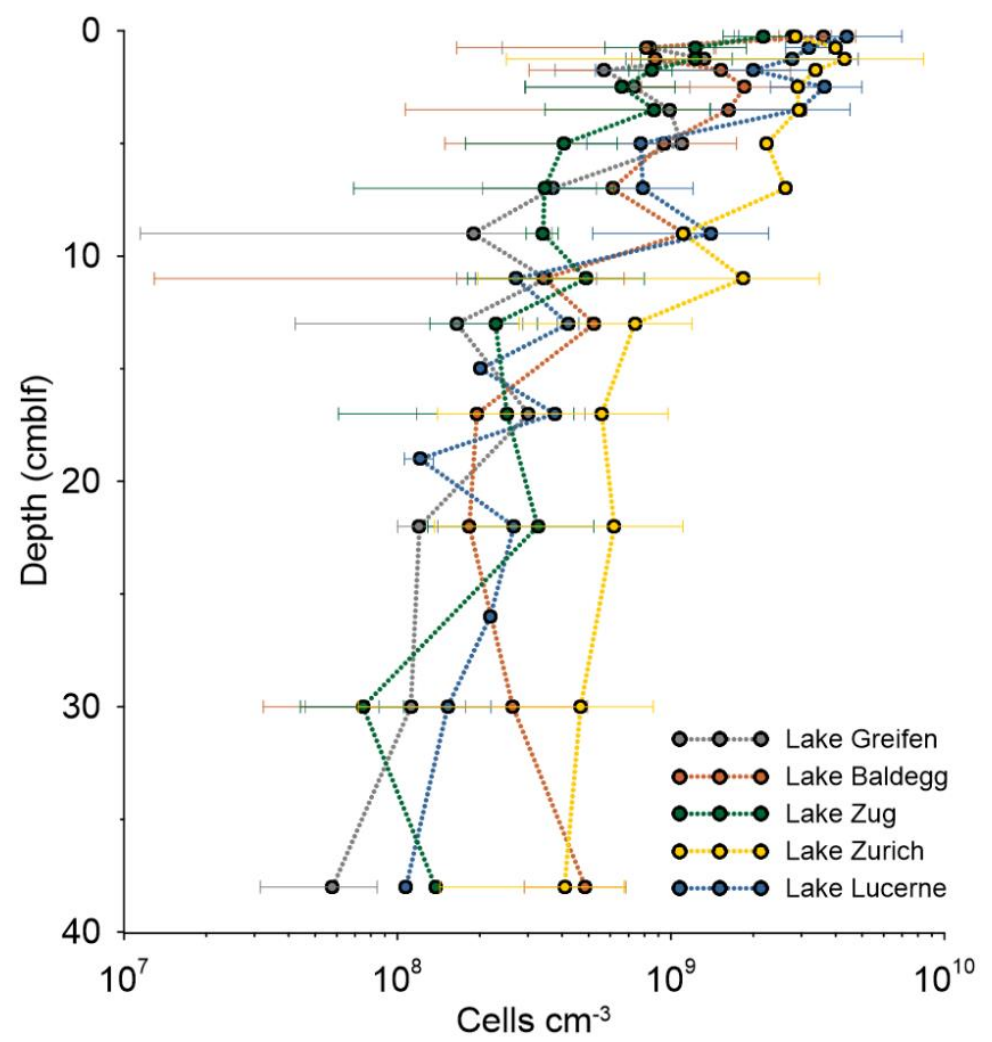

Figure S7: Average cell numbers (3 station average) vs depth. Error bars indicate standard deviations for the average of the 3 stations. 

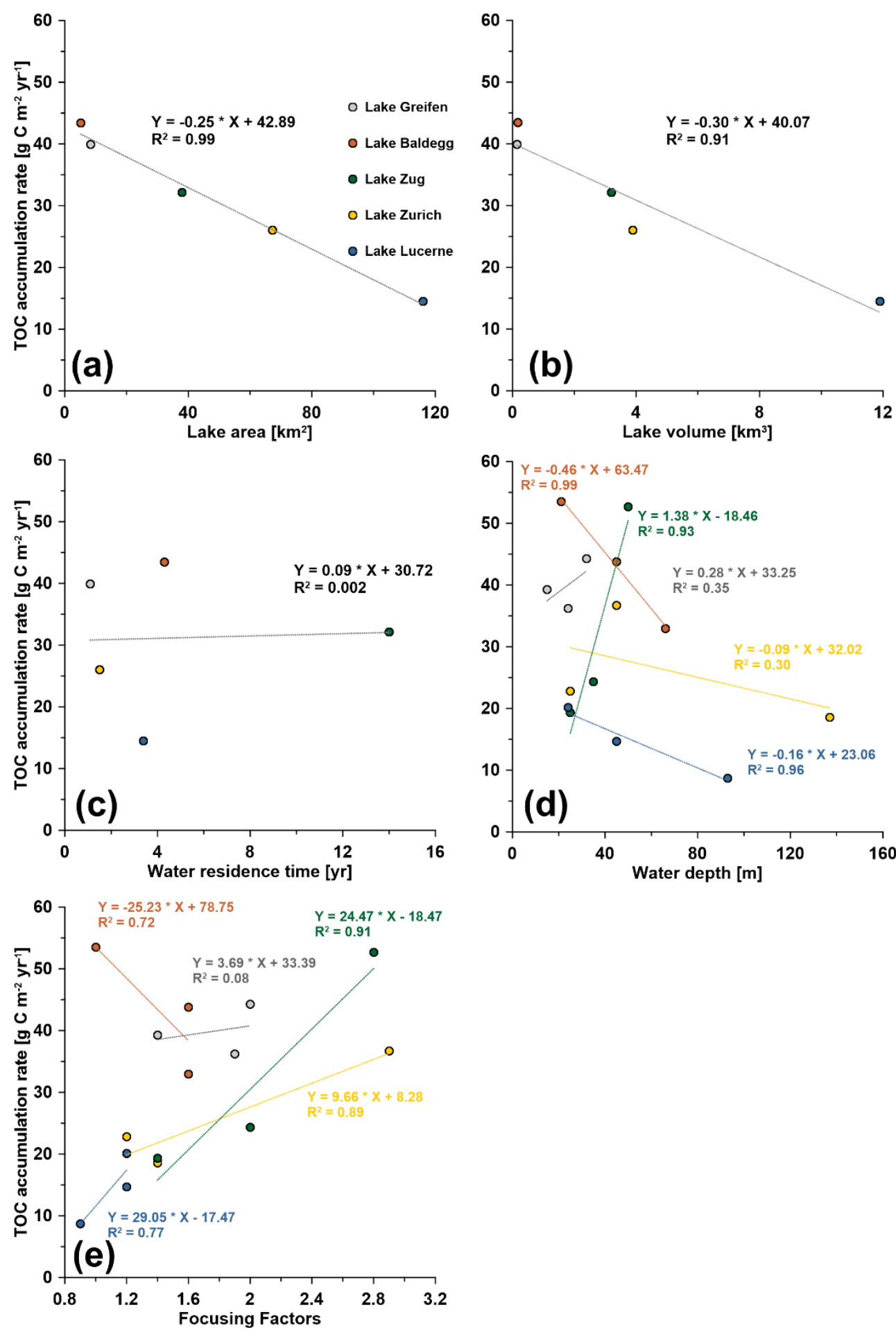

Figure S8: TOC accumulation rates (1840-2016) vs. (a) lake area, (b) lake volume, (c) water residence time, (d) water depth, and (e) focusing factors. Linear correlation equations and $R^{2}$ are indicated in each subplot. For a, $b$ and $c$, TOC accumulation rates of the 3 stations per lake are averaged. 


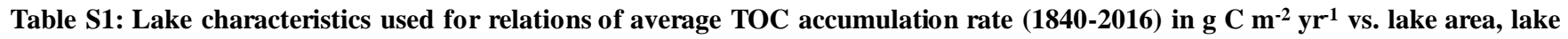
volume, water residence times, water depth and focusing factors.

\begin{tabular}{|c|c|c|c|c|c|c|c|c|}
\hline & $\begin{array}{l}\text { Area } \\
\left(\mathbf{k m}^{2}\right)\end{array}$ & $\begin{array}{c}\text { Volume } \\
\left(\mathbf{k m}^{\mathbf{3}}\right)\end{array}$ & $\begin{array}{c}\text { Water } \\
\text { residence time } \\
{[\mathrm{yr}]}\end{array}$ & St. (\#) & $\begin{array}{c}\text { Water depth } \\
\text { (m) }\end{array}$ & FF & $\begin{array}{c}\text { TOC accum. } \\
\text { rates }\end{array}$ & $\begin{array}{c}\text { AV } \\
\text { TOC } \\
\text { accum. } \\
\text { rates }\end{array}$ \\
\hline \multirow{3}{*}{$\begin{array}{c}\text { Lake } \\
\text { Greifen }\end{array}$} & \multirow{3}{*}{8.4} & \multirow{3}{*}{0.148} & \multirow{3}{*}{1.1} & 2 & 33 & 2.0 & 44.3 & \multirow{3}{*}{39.9} \\
\hline & & & & 3 & 24 & 1.9 & 36.2 & \\
\hline & & & & 1 & 15 & 1.4 & 39.3 & \\
\hline \multirow{3}{*}{$\begin{array}{c}\text { Lake } \\
\text { Baldegg }\end{array}$} & \multirow{3}{*}{5.2} & \multirow{3}{*}{0.173} & \multirow{3}{*}{4.3} & 1 & 68 & 1.6 & 33.0 & \multirow{3}{*}{43.3} \\
\hline & & & & 2 & 45 & 1.6 & 43.8 & \\
\hline & & & & 3 & 21 & 1.0 & 53.5 & \\
\hline \multirow{3}{*}{ Lake Zug } & \multirow{3}{*}{38} & \multirow{3}{*}{3.2} & \multirow{3}{*}{14} & 3 & 50 & 2.8 & 19.3 & \multirow{3}{*}{32.1} \\
\hline & & & & 2 & 35 & 2.0 & 24.3 & \\
\hline & & & & 1 & 25 & 1.4 & 52.7 & \\
\hline \multirow{3}{*}{$\begin{array}{c}\text { Lake } \\
\text { Zurich }\end{array}$} & \multirow{3}{*}{67.3} & \multirow{3}{*}{3.9} & \multirow{3}{*}{1.5} & 1 & 137 & 1.4 & 22.8 & \multirow{3}{*}{26.0} \\
\hline & & & & 2 & 45 & 2.9 & 36.7 & \\
\hline & & & & 3 & 25 & 1.2 & 18.5 & \\
\hline \multirow{3}{*}{$\begin{array}{c}\text { Lake } \\
\text { Lucerne }\end{array}$} & \multirow{3}{*}{116} & \multirow{3}{*}{11.9} & \multirow{3}{*}{3.4} & 2 & 93 & 0.9 & 8.7 & \multirow{3}{*}{14.5} \\
\hline & & & & 3 & 45 & 1.2 & 36.7 & \\
\hline & & & & 1 & 24 & 1.2 & 22.8 & \\
\hline
\end{tabular}




\section{References}

AKV 2014: Aufsichtskommission Vierwaldstättersee. Kantone Luzern, Nidwalden, Obwalden, Schwyz und Uri. http://www.4waldstaettersee.ch/04.2_see.html, last access: 18 March 2019.

AquaPlus 2001: Entwicklung des Gesamtphosphors im Zugersee anhand der im Sediment eingelagerten Kieselalgen. Bericht 5 zuhanden des Amtes für Umweltschutz des Kantons Zug, $48 \mathrm{~S}$.

AquaPlus 2004: Untersuchung der Fliessgewässer und Seen im Kanton Zug und im Einzugsgebiet des Zugersees. Bericht zuhanden des Amtes für Umweltschutz des Kantons Zug, $86 \mathrm{~S}$.

AquaPlus 2004: Entwicklung des Gesamtphosphors im Greifensee anhand der im Sediment eingelagerten Kieselalgen.

Bericht zuhanden des Amtes für Abfall, Wasser, Energie und Luft des Kantons Zürich.

10 AWEL 2014: Seen: Auswertung nach Kenngrössen. Amt für Abfall, Wasser, Energie und Luft des Kantons Zürich. www.awel.zh.ch/internet/baudirektion/awel/de/wasserwirtschaft/gewaesserqualitaet/seen_kenngroessen.html, last access: 18 March 2019.

AWEL 2014: Seen: Auswertung nach Kenngrössen. Amt für Abfall, Wasser, Energie und Luft des Kantons Zürich. www.awel.zh.ch/internet/baudirektion/awel/de/wasserwirtschaft/gewaesserqualitaet/seen_kenngroessen.html, last access: 18

15 March 2019.

BAFU, 2013: Einzugsgebiets gliederung Schweiz EZGG-CH, Bundesamt für Umwelt, Bern. http://www.bafu.admin.ch/hydrologie/01835/11452/index.html., last access: 18 March 2019.

BFS, 2010: Betriebszählung 2008. Branchenporträt Landwirtschaft. BFS Aktuell. Bundesamt für Statistik, Neuchâtel, 18 S. www.bfs.admin.ch/bfs/portal/de/index/infothek/erhebungen_quellen/blank/blank/bzs1z/01.html, last access: 18 March

202019.

BFS, 2011: Statistik der Bevölkerung und der Haushalte 2011 (STATPOP2011), Bundesamt für Statistik, Neuchâtel. Buergi, H. R. and Stadelmann, P.: Change of phytoplankton diversity during long-term restoration of Lake Baldegg (Switzerland), Int Ver Theor Angew, 27, 574-581, 2000.

Cole, J. J., Prairie, Y. T., Caraco, N. F., McDowell, W. H., Tranvik, L. J., Striegl, R. G., Duarte, C. M., Kortelainen, P.,

25 Downing, J. A., Middelburg, J. J., and Melack, J.: Plumbing the global carbon cycle: Integrating inland waters into the terrestrial carbon budget, Ecosystems, 10, 171-184, 2007.

Gammeter, S., Forster, R., and Wasserversorgung: Langzeituntersuchungen im Zürichobersee 1972-2000 Bericht zuhanden des Baudepartements des Kantons St. Gallen, des Departementes des Innern des Kantons Schwyz sowie der Direktion für Landwirtschaft, Wald und Umwelt des Kantons Glarus, Wasserversorgung Zürich, Zürich, 2002.

30 Gammeter, S., Forster, R., Zimmermann, U., and Wasserversorgung: Limnologische Untersuchung des Zürichsees 19721996, Wasserversorgung, Zürich, 1997.

Hermanson, M. H. and Christensen, E. R.: Recent Sedimentation in Lake-Michigan, J Great Lakes Res, 17, 33-50, 1991. Jankowski, T. and Weyhenmeyer, G. A.: The role of spatial scale and area in determining richness-altitude gradients in Swedish lake phytoplankton communities, Oikos, 115, 433-442, 2006.

35 Känel: Zürcher Gewässer, Entwicklung-Zustand-Ausblick, 2012. 2012.

Kluepfel, L., Keiluweit, M., Kleber, M., and Sander, M.: Redox Properties of Plant Biomass-Derived Black Carbon (Biochar), Environ Sci Technol, 48, 5601-5611, 2014.

Klupfel, L., Piepenbrock, A., Kappler, A., and Sander, M.: Humic substances as fully regenerable electron acceptors in recurrently anoxic environments, Nat Geosci, 7, 195-200, 2014.

40 Kümmerlin, R. E. and Matzinger, A.: Zirkulationsunterstützung im Türlersee und Pfäffikersee Evaluation von Betrieb und Messprogramm, Eawag, Kastanienbaum, 2008.

Liechti, P.: Der Zustand der Seen in der Schweiz, Bundesamt für Umwelt, Bern, 1994. 
Livingstone, D. M.: Impact of secular climate change on the thermal structure of a large temperate central European lake, Climatic Change, 57, 205-225, 2003.

Lotter, A.: The effect of eutrophication on diatom diversity: examples from six Swiss lakes, 2001. 2001.

Lotter, A. F.: The recent eutrophication of Baldeggersee (Switzerland) as assessed by fossil diatom assemblages, Holocene,

5 8, 395-405, 1998.

Maerki, M., Muller, B., Dinkel, C., and Wehrli, B.: Mineralization pathways in lake sediments with different oxygen and organic carbon supply, Limnol Oceanogr, 54, 428-438, 2009.

Sander, M., Hofstetter, T. B., and Gorski, C. A.: Electrochemical Analyses of Redox-Active Iron Minerals: A Review of Nonmediated and Mediated Approaches, Environ Sci Technol, 49, 5862-5878, 2015.

10 South, A.: rworldmap: A New R package for Mapping Global Data, R J, 3, 35-43, 2011.

Stadelmann, P. and Escher, M.: 20 Jahre Sanierung und Ueberwachung des Baldeggersees, Naturforschende Gesellschaft, Luzern, 2002.

Staub, E. A., Ambühl, H., and Hsü, K. J.: Diagenese im rezenten Sediment des Vierwaldstättersees und ihre Veränderung durch die Eutrophierung Tiefenprofile biologisch-chemischer Parameter im Sediment und Porenwasser, 1981.Diss Naturwiss

15 ETH Zürich, Nr 6841, 0000 Ref Ambühl, H Korref Hsü, K J, VII, 224 S. pp., 1981.

Teranes, J. L., McKenzie, J. A., and Lotter, A. F.: Stable isotope response to lake eutrophication: Calibration of a highresolution lacus trine sequence from Baldeggersee, Switzerland, Limnol Oceanogr, 44, 320-333, 1999.

Vissers, E. W., Blaga, C. I., Bodelier, P. L., Muyzer, G., Schleper, C., Sinninghe Damste, J. S., Tourna, M., and Laanbroek, H. J.: Seasonal and vertical distribution of putative ammonia-oxidizing thaumarchaeotal communities in an oligotrophic

20 lake, Fems Microbiol Ecol, 83, 515-526, 2013.

Water quality in lakes: https://www.bafu.admin.ch/bafu/en/home/topics/water/info-specialists/state-of-waterbodies/state-oflakes/water-quality-in-lakes.html, last access: 18 March 2019. 